BNL- 66727

Informal Report

\title{
PRELIMINARY EVALUATION OF POTENTIAL OCCUPATIONAL AND PUBLIC HEALTH IMPACTS OF SEDIMENT DECONTAMINATION FACILITIES FOR NEW YORK/NEW JERSEY HARBOR
}

\author{
Michael D. Rowe \\ Robert C. Klein \\ Keith W. Jones
}

July 1999

Prepared for

US Environmental Protection Agency Region 2

Under Interagency Grant No. DW89941761-01

Brookhaven National Laboratory

Brookhaven Science Associates

Upton, New York 11973 


\section{DISCLAIMER}

This report was prepared as an account of work sponsored by an agency of the United States Government. Neither the United States Government nor any agency thereof, nor any of their employees, nor any of their contractors, subcontractors, or their employees, makes any warranty, express or implied, or assumes any legal liability or responsibility for the accuracy, completeness, or usefulness of any information, apparatus, product, or process disclosed, or represents that its use would not infringe privately owned rights. Reference herein to any specific commercial product, process, or service by trade name, trademark, manufacturer, or otherwise, does not necessarily constitute or imply its endorsement, recommendation, or favoring by the United States Government or any agency, contractor, or subcontractor thereof. The views and opinions of authors expressed herein do not necessarily state or reflect those of the United States Government or any agency, contractor, or subcontractor thereof.

Printed in the United States of America

Available from

National Technical Information Service

US Department of Commerce 5285 Port Royal Road

Springfield, VA 22161 
BNL-

Informal Report

\title{
PRELIMINARY EVALUATION OF POTENTIAL OCCUPATIONAL AND PUBLIC HEALTH IMPACTS OF SEDIMENT DECONTAMINATION FACILITIES FOR NEW YORK/NEW JERSEY HARBOR
}

\author{
Michael D. Rowe \\ Robert C. Klein \\ Keith W. Jones
}

July 1999

Prepared for

US Environmental Protection Agency Region 2

Under Interagency Grant No. DW89941761-01

Brookhaven National Laboratory

Brookhaven Science Associates

Upton, New York 11973

Under Contract No. DE-AC02-98CH10886 with the

United States Department of Energy 


\section{INTRODUCTION}

Sediment is accumulating in New York/New Jersey Harbor, and shipping channels are rapidly becoming too shallow for large ships. The Port Authority of New York/New Jersey has determined that dredging of the ship channels is essential to keep them navigable. About five million cubic yards of sediment must be removed per year to keep the channels open. Without dredging, the channels will soon become unusable, and the shoreside shipping and warehousing businesses that depend on them will fade away. The economic loss to the area would be devastating.

But the deeper layers of sediment in the Harbor contain a broad range of pollutants that are hazardous to humans and the environment--a legacy of past discharges that are no longer permitted. These include heavy metals, polycyclic aromatic hydrocarbons (PAHs), polychlorinated biphenyls (PCBs), chlorinated pesticides, and dioxins. As a result, there are several million cubic yards of sediments to be dredged per year that do not meet applicable criteria for ocean disposal and must be dealt with in some other way.

A possible solution to the problem is to treat the dredged material to immobilize or destroy the contaminants and make the treated sediments suitable for disposal in the ocean or on land at acceptable cost. A variety of technologies can be used to achieve this goal. The simplest approach is to make manufactured soil from untreated sediment. The most complex approaches involve hightemperature destruction of organic contaminants and immobilization of inorganic contaminants. When any of these technologies are used, there is potential for risks to human health from process wastes and from the treated materials themselves. Also, disposal or beneficial use of treated materials may generate other risks to human health or the environment. A description of some of the technologies considered is given in Table 1. Success in removing or immobilizing the contaminants, which varies significantly among technologies, is reported elsewhere. ${ }^{1}$

This report provides a preliminary evaluation, or "screening assessment," of potential occupational, public, and environmental health risks from dredging, transporting, and treating contaminated harbor sediments with thermal treatment methods to render them suitable for disposal or beneficial use. The assessment was done in stages as the project advanced and data became available from other tasks on characteristics of sediments and treatment processes.

Preliminary screening assessments included estimates of potential occupational and public health risks. The following categories of exposure and risk are addressed with varying degrees of specificity, depending on the data available at this early stage of the project:

- General physical and chemical occupational hazards associated with all dredging;

- Specific occupational exposures from inhalation of contaminants emitted by thermal decontamination facilities;

- Public exposures from ingestion of recreational seafood living on undredged contaminated sediments in situ; 
Table 1. Sediment decontamination technologies tested.

\begin{tabular}{|c|c|c|c|}
\hline Company & Technology & Description & $\begin{array}{c}\text { Suggested } \\
\text { Beneficial Uses }\end{array}$ \\
\hline $\begin{array}{l}\text { BioGenesis } \\
\text { Enterprises }\end{array}$ & $\begin{array}{l}\text { Surfactant- } \\
\text { based soil- } \\
\text { washing }\end{array}$ & $\begin{array}{l}\text { Wastewater is treated by chemical } \\
\text { precipitation to remove metals, followed } \\
\text { by UV/oxidation to destroy organic } \\
\text { contaminants. }\end{array}$ & $\begin{array}{l}\text { Landfill cover, } \\
\text { topsoil } \\
\text { replacement, } \\
\text { manufactured } \\
\text { topsoil }\end{array}$ \\
\hline BioSafe, Inc. & $\begin{array}{l}\text { Fluidized-bed } \\
\text { steam } \\
\text { stripping }\end{array}$ & $\begin{array}{l}\text { Volatilize organic contaminants by } \\
\text { thermal desorption at temperatures up to } \\
1200^{\circ} \mathrm{F} \text {, followed by thermal destruction } \\
\text { of organic contaminants at } 2200^{\circ} \mathrm{F} \text {. } \\
\text { Metals remaining in the sediment can be } \\
\text { treated by metals-removal processes, if } \\
\text { necessary. }\end{array}$ & $\begin{array}{l}\text { Landfill cover, } \\
\text { construction } \\
\text { backfill }\end{array}$ \\
\hline $\begin{array}{l}\text { Institute of Gas } \\
\text { Technology }\end{array}$ & $\begin{array}{l}\text { Cement- } \\
\text { LockTM }^{\text {TM }}\end{array}$ & $\begin{array}{l}\text { Sediments are reacted with modifiers in a } \\
\text { melter at } 2500^{\circ} \mathrm{F} \text {. Organic contaminants } \\
\text { are destroyed and metals are immobilized } \\
\text { in a salable cement matrix. }\end{array}$ & $\begin{array}{l}\text { Construction- } \\
\text { grade cement }\end{array}$ \\
\hline IT Corporation & $\begin{array}{l}\text { Thermal- } \\
\text { desorption }\end{array}$ & $\begin{array}{l}\text { Temperatures up to } 1000^{\circ} \mathrm{F} \text { volatilize } \\
\text { organic contaminants for subsequent } \\
\text { treatment, followed by chemical } \\
\text { stabilization of treated sediments to } \\
\text { immobilize metals. }\end{array}$ & Artificial reefs \\
\hline $\begin{array}{l}\text { Marcor } \\
\text { Environmental } \\
\text { and } \\
\text { Kiber, Inc. }\end{array}$ & $\begin{array}{l}\text { Chemical } \\
\text { stabilization }\end{array}$ & $\begin{array}{l}\text { Aluminum-silica-oxide reagent } \\
\text { mineralizes organic contaminants and } \\
\text { metals in a solid matrix. Exothermic } \\
\text { reaction. }\end{array}$ & $\begin{array}{l}\text { Construction } \\
\text { backfill, } \\
\text { secondary } \\
\text { building } \\
\text { material }\end{array}$ \\
\hline $\begin{array}{l}\text { Metcalf and } \\
\text { Eddy }\end{array}$ & $\begin{array}{l}\text { Solvent } \\
\text { extraction } \\
\text { with } \\
\text { stabilization }\end{array}$ & $\begin{array}{l}\text { Separate sediments by size, then (a) } \\
\text { remove organic contaminants with } \\
\text { solvent extraction, or (b) stabilize with a } \\
\text { cement-based binding agent to } \\
\text { immobilize organic contaminants and } \\
\text { metals, or (c) both solvent extraction and } \\
\text { stabilization. }\end{array}$ & $\begin{array}{l}\text { Landfill cover, } \\
\text { construction } \\
\text { backfill, } \\
\text { highway } \\
\text { sub-base } \\
\text { aggregate }\end{array}$ \\
\hline $\begin{array}{l}\text { Westinghouse } \\
\text { Science and } \\
\text { Technology } \\
\text { Center }\end{array}$ & $\begin{array}{l}\text { Plasma-arc } \\
\text { vitrification }\end{array}$ & $\begin{array}{l}\text { Heat sediments as high as } 5000^{\circ} \mathrm{F} \text {, which } \\
\text { destroys organic contaminants and } \\
\text { immobilizes metals in a glass-like matrix. }\end{array}$ & $\begin{array}{l}\text { Fiberglass, glass } \\
\text { fiber products, } \\
\text { rock wool } \\
\text { insulation, frit } \\
\end{array}$ \\
\hline \multirow[t]{2}{*}{$\begin{array}{l}\text { Waterways } \\
\text { Experiment } \\
\text { Station }\end{array}$} & $\begin{array}{l}\text { Solidification/ } \\
\text { stabilization }\end{array}$ & $\begin{array}{l}\text { Portland cement and lime/flyash are } \\
\text { added as binding agents to immobilize } \\
\text { organic contaminants and metals. }\end{array}$ & $\begin{array}{l}\text { Construction } \\
\text { backfill, } \\
\text { secondary } \\
\text { building } \\
\text { material, } \\
\text { artificial reefs }\end{array}$ \\
\hline & $\begin{array}{l}\text { Manufactured } \\
\text { soil }\end{array}$ & $\begin{array}{l}\text { Sediment is diluted with clean material, } \\
\text { fertilizers, and soil conditioners. }\end{array}$ & $\begin{array}{l}\text { Landfill cover, } \\
\text { construction } \\
\text { backfill }\end{array}$ \\
\hline
\end{tabular}


- Public exposures from inhalation of contaminants emitted by thermal decontamination facilities; and

- Public exposures from ingestion of surface dusts from decontamination facilities.

Estimates of specific exposures to workers and the public were made first for a pilot-scale facility processing one $\mathrm{yd}^{3}$ of sediment per day. These results were then scaled up without change to a facility processing $1370 \mathrm{yd}^{3}$ per day $\left(500,000 \mathrm{yd}^{3} / \mathrm{yr}\right)$. Preliminary assessments were upgraded with detailed characterizations of the sediments as they became available. Where applicable, we have also included monitoring and assessment data from recent sediment projects on Newtown Creek and the Passaic River, locations considered among the most contaminated in the harbor.

At the time of this writing, no data were available on emissions from pilot-scale decontamination facilities, so it was not possible to estimate health impacts of post-scrubber emissions directly. Therefore, data and assumptions from the screening assessment were used to estimate health-based emissions limits -- maximum permissible emission rates above which health-based exposure criteria are predicted to be exceeded within the treatment plant or at the maximum residential exposure. These can be used to determine which contaminants and exposure pathways are worth examining in more detail when more data become available.

Because of the changes in the quantity and quality of available data as the project progressed, there are some small inconsistencies between earlier and later reports. We expect that there will be more such changes and inconsistencies in the future as the quality of the specific data available on emissions characteristics of the decontamination technologies improves.

\section{OCCUPATIONAL HEALTH RISKS}

All dredging and materials handling activities carry readily identifiable occupational hazards and associated risks. Besides traditional shipboard hazards (e.g., drowning, injuries related to heavy equipment operation, noise), handling contaminated sediments also creates potential for exposure to toxic chemicals and pathogens. Occupational hazards are specific to the circumstances and, since operations and their hazards often change during a project, they should be reviewed and updated regularly.

The general categories of hazards identified are:

\section{Physical Hazards}

- Safety -- Drowning, falling objects, misuse of equipment, ergonomic/repetitive motion injuries, slips, trips, falls, crushes, and cuts.

- Explosion and Fire -- Ignition of petroleum products; methane, hydrogen, or hydrogen sulfide.

- Container Pressurization -- Gases from biological or chemical degredation.

- Electricity -- Faulty wiring, grounding.

- Heat and Cold Stress -- Outdoor work.

- Noise -- Engines and compressors. 


\section{Health Hazards}

- Oxygen Deficiency -- Sediments in closed containers.

- Pathogens -- Human or medical wastes, tetanus; infection from inhalation, ingestion, or cuts.

- Toxic or Carcinogenic Chemicals -- Inhalation or ingestion of sediments, offgases; processing chemicals, or solvents.

- Ionizing Radiation -- Radionuclides in sediments.

These occupational hazards are common in other industrial environments, and mitigation measures are well established ${ }^{2}$ It can be assumed, therefore, that good planning, good design, and good safety practices will be followed and that risks from most of these hazards will be comparable to those in similar industries.

Occupational hazards specific to decontamination of sediments from New York/New Jersey Harbor are confined to direct exposure to any unusually high concentrations of hazardous materials in the sediments or offgases and any processing residuals specific to individual sediment decontamination technologies. Since occupational exposures to hazardous materials are regulated by the Occupational Safety and Health Administration (OSHA), working environments for all sediment treatment technologies must necessarily meet OSHA standards, and occupational risks must be less than or equal to those implied by the standards, which are "acceptable" by definition. The task of evaluating occupational risks is confined to determining which hazardous materials have potential to exceed OSHA or other relevant standards and, therefore, require special attention and mitigation measures to ensure compliance. These are discussed individually below.

\subsection{FIRE}

Sediments containing organic matter can generate methane (marsh gas) and (if anoxic) hydrogen sulfide which can be liberated during dredging and processing. These gases are flammable in air:

\begin{tabular}{lc} 
Gas & Flammable Range \\
\hline Hydrogen sulfide & $4-45 \%$ (by volume in air) \\
Methane & $5-15 \%$ (by volume in air).
\end{tabular}

Although the odor threshold for hydrogen sulfide is well below 1 part per million (ppm), the nose fatigues quickly to hydrogen sulfide, making it an inappropriate detector for this gas. It is very unlikely that atmospheric levels of these chemicals could reach flammable limits in open areas, but precautions should still be taken to prevent buildup in closed containers. Sediment grab samples should be surveyed with a portable gas detector as they are deposited on deck as well as prior to packaging and shipping.

\subsection{OXYGEN DEFICIENCY}

Under OSHA regulations, workers may not be subjected to atmospheres containing less than $19.5 \%$ oxygen. Although work in well-ventilated spaces should never produce an oxygen deficiency, storage of sediments in closed or partially closed containers could. If these containers are large enough and so constructed that a worker could enter them, the space may qualify as a confined space 
and require monitoring for oxygen as well as other chemical or physical parameter(s) that could injure those working nearby or entering into the container.

\subsection{TOXINS AND CARCINOGENS}

Occupational contact with sediment contaminants can occur by ingestion, inhalation, dermal (transfer through skin), or percutaneous (direct injection or puncture wound entry) exposure. Good practices that ensure compliance with OSHA standards will usually suffice in any normal industrial environment. But some care must be taken to avoid excessive conservatism in protective measures. Unnecessarily cumbersome work procedures or protective equipment may increase rather than decrease workers' risks. Respirators and many other kinds of personal protective equipment reduce inter-personal communications and encapsulating outer garments significantly increase heat stress and cardio-pulmonary demands. A rational approach to managing occupational risk from contaminated sediments must balance these risks with their benefits.

Inhalation is the most probable route for occupational exposure to contaminants in sediments. Assessments of inhalation exposure typically involve comparison of worst-case estimates of airborne contaminant concentrations in the breathing zone with exposure limits established by the Occupational Safety and Health Administration (OSHA) and the American Conference of Governmental Industrial Hygienists (ACGIH). These limits, known respectively as Permissible Exposure Limits (PELs) ${ }^{3}$ and Threshold Limit Values (TLVs) ${ }^{4}$, represent the maximum airborne concentration of a contaminant to which workers may be continuously exposed for 8 hours per day, 40 hours per week, for their working lifetime. Where differences exist between the limits set by OSHA and ACGIH, the lower, more conservative value should be used. For multiple contaminants of concern, the sum of the ratio of each contaminant's worst-case concentration divided by its corresponding allowable exposure limit (AEL) ([Worst concentration]/AEL +[Worst concentration]/AEL...+$)$ can be used to evaluate total exposure. If the sum equals or exceeds 1 , then a potential for over-exposure exists and additional controls (such as modifying work practices or operational equipment, or increasing the level of personal protective equipment to include respirators) must be implemented.

Although we do not yet have information on emissions from raw sediment handling or the various treatment technologies being tested, information is available on the physical environments in which they may occur. We can, therefore, back-calculate the emission rates required to produce exposures equal to applicable standards or health-risk limits. These represent an upper limit on emissions against which projected emission rates can be compared and from which we can determine those toxins and carcinogens that require closer attention and more careful management.

2.3.1 Dredging. Test sediments for this project were obtained from Newtown Creek (Table 2). Analyses for 40 common volatile chemicals in freshly dredged sediments and in container headspaces yielded concentrations below analytical detection limits. Hydrogen sulfide from this anoxic sediment barely reached $1 \mathrm{ppm}$, and volatile chemicals were absent in bulk chemical analyses, despite a weak odor of petroleum hydrocarbons.

Aerosols were measured with a real-time direct-reading particle meter immediately after clam shell ( 0.1 and 1 cubic yard capacity devices) loads were dropped into large, semi-enclosed, roll-off 
containers. Measurements were collected at the sediment surface and at various locations above the deposited material to a distance of 6 feet. Maximum aerosol concentration was $0.1 \mathrm{mg} / \mathrm{m}^{3}$, with the majority of measurements between $0.01-0.05 \mathrm{mg} / \mathrm{m}^{3}$. The worst-case exposure scenario for aerosolized sediment from this work was, therefore, calculated by assuming that a theoretical worker continuously breathes aerosolized sediment at a concentration of $0.1 \mathrm{mg} / \mathrm{m}^{3}$ for 8 hours (Table 3).

Table 2. Properties of sediments from Newtown Creek, New York, used in pilot tests of decontamination technologies. Contaminant concentrations are dry weights.

Solids content

Particle size (solid phase)

$\mathrm{pH}$

Total organic carbon

Sulfides (total)

Dioxins and Furans (TEQ)

Chlorinated herbicides (total)

Chlorinated pesticides (total)

Polychlorinated biphenyls

Dioxin-like (TEQ)

Non-dioxin-like

Polynuclear aromatic hydrocarbons (Class B2)

Metals:

Antimony

Arsenic

Beryllium

Cadmium

Chromium (total)

Copper

Lead

Mercury (total)

Nickel

Selenium

Silver

Thallim

Zinc
$31 \%$

$81 \%$ clays and silts

0.9

$2.3 \%$

$2600 \mathrm{mg} / \mathrm{kg}$

$0.52 \mu \mathrm{g} / \mathrm{kg}$

$0.30 \mathrm{mg} / \mathrm{kg}$

$2.3 \mathrm{mg} / \mathrm{kg}$

$0.073 \mu \mathrm{g} / \mathrm{kg}$

$5.1 \mathrm{mg} / \mathrm{kg}$

$13 \mathrm{mg} / \mathrm{kg}$

$10 \mathrm{mg} / \mathrm{kg}$

$33 \mathrm{mg} / \mathrm{kg}$

$0.56 \mathrm{mg} / \mathrm{kg}$

$37 \mathrm{mg} / \mathrm{kg}$

$380 \mathrm{mg} / \mathrm{kg}$

$1200 \mathrm{mg} / \mathrm{kg}$

$620 \mathrm{mg} / \mathrm{kg}$

$1.3 \mathrm{mg} / \mathrm{kg}$

$300 \mathrm{mg} / \mathrm{kg}$

$3.2 \mathrm{mg} / \mathrm{kg}$

$18 \mathrm{mg} / \mathrm{kg}$

$2.3 \mathrm{mg} / \mathrm{kg}$

$1700 \mathrm{mg} / \mathrm{kg}$ 
Table 3. Derived maximum concentrations of contaminatns in aerosols generated during dredging and mixing of estuarine sediments from Newtown Creek, New York. These estimates assume the highest actual aerosol concentration measured $\left(0.1 \mathrm{mg} / \mathrm{m}^{3}\right)$.

\begin{tabular}{|c|c|c|c|c|c|}
\hline Contaminant & $\begin{array}{l}\text { Vapor } \\
\text { Pressure } \\
\text { (mm Hg) }\end{array}$ & $\begin{array}{c}\text { Wet } \\
\text { Concentration }\end{array}$ & $\begin{array}{c}\text { Maximum } \\
\text { Contaminant } \\
\text { Concentration } \\
\text { in Aerosol }\end{array}$ & $\begin{array}{l}\text { Allowable } \\
\text { Exposure } \\
\text { Limit }^{2}\end{array}$ & $\begin{array}{l}\text { Max. } \\
\text { Conc./ } \\
\text { Exposure } \\
\text { Limit }\end{array}$ \\
\hline Dioxins (total) & $\ll 1$ & $7.9 \mu \mathrm{g} / \mathrm{kg}$ & $0.79 \mathrm{pg} / \mathrm{m}^{3}$ & $\mathrm{NE}^{\mathrm{b}}$ & \\
\hline $2,3,7,8-\mathrm{TCDD}$ & $\overline{<<1}$ & $0.013 \mu \mathrm{g} / \mathrm{kg}$ & $0.0013 \mathrm{pg} / \mathrm{m}^{3}$ & $70 \mathrm{pg} /$ day $^{\mathrm{c}}$ & $1.9 \times 10^{-5}$ \\
\hline Furans (total) & $<<1$ & $6.9 \mu \mathrm{g} / \mathrm{kg}$ & $0.69 \mathrm{pg} / \mathrm{m}^{3}$ & $\mathrm{NE}$ & \\
\hline $2,3,7,8-\mathrm{TCDF}$ & $\overline{<<1}$ & $0.113 \mu \mathrm{g} / \mathrm{kg}$ & $0.0113 \mathrm{pg} / \mathrm{m}^{3}$ & $\mathrm{NE}$ & \\
\hline $\begin{array}{l}\text { Chlorinated } \\
\text { herbicides (total) }\end{array}$ & $<<1$ & $\begin{array}{l}<0.05-0.2 \\
\mathrm{mg} / \mathrm{kg}\end{array}$ & $\begin{array}{l}<0.005-0.02 \\
\mathrm{ng} / \mathrm{m}^{3}\end{array}$ & $\overline{\mathrm{NE}}$ & \\
\hline $\begin{array}{l}\text { Chlorinated } \\
\text { pesticides (total) }\end{array}$ & 0.0001 & $141 \mu \mathrm{g} / \mathrm{kg}$ & $14.1 \mathrm{pg} / \mathrm{m}^{3}$ & $\begin{array}{l}0.25 \mathrm{mg} / \mathrm{m}^{3} \\
\text { (Aldrin) }\end{array}$ & $5.6 \times 10^{-8}$ \\
\hline $\begin{array}{l}\text { Polychlorinated } \\
\text { biphenyls (total } \\
\text { mono-decachloro) }\end{array}$ & $\begin{array}{l}0.001 \\
(\max )\end{array}$ & $1.33 \mathrm{mg} / \mathrm{kg}$ & $0.133 \mathrm{ng} / \mathrm{m}^{3}$ & $0.5 \mathrm{mg} / \mathrm{m}^{3}$ & $2.6 \times 10^{-7}$ \\
\hline $\begin{array}{l}\text { Polynuclear } \\
\text { aromatic } \\
\text { hydrocarbons (total) }\end{array}$ & $\ll 1$ & $18.3 \mathrm{mg} / \mathrm{kg}$ & $1.83 \mathrm{ng} / \mathrm{m}^{3}$ & $0.2 \mathrm{mg} / \mathrm{m}^{3}$ & $9.2 \times 10^{-6}$ \\
\hline Metals: & & $\mathrm{mg} / \mathrm{kg}$ & $\mathrm{ng} / \mathrm{m}^{3}$ & $\mu \mathrm{g} / \mathrm{m}^{3}$ & \\
\hline Antimony & 0 & 3.3 & 0.33 & 500 & $6.6 \times 10^{-7}$ \\
\hline Arsenic & 0 & 11 & 1.1 & 10 & $1.1 \times 10^{-4}$ \\
\hline Beryllium & 0 & 0.2 & 0.02 & 2 & $1.0 \times 10^{-5}$ \\
\hline Cadmium & 0 & 12.3 & 1.23 & 2 & $6.1 \times 10^{-4}$ \\
\hline Chromium (total) & $\overline{0}$ & 125.6 & 12.56 & 10 & $1.2 \times 10^{-3}$ \\
\hline Copper & 0 & 391 & 39.1 & 1 & $3.9 \times 10^{-5}$ \\
\hline Lead & 0 & 206 & 20.6 & 50 & $4.1 \times 10^{-4}$ \\
\hline Mercury (total) & $\begin{array}{l}0.0012 \\
(\max )\end{array}$ & 0.43 & 0.043 & 10 & $4.3 \times 10^{-6}$ \\
\hline Nickel & 0 & 99 & 9.9 & 100 & $9.9 \times 10^{-5}$ \\
\hline Silver & $\overline{0}$ & 6 & 0.6 & 10 & $6.0 \times 10^{5}$ \\
\hline$\overline{\text { Zinc }}$ & 0 & 575 & 57.5 & 5 & $1.1 \times 10^{-5}$ \\
\hline
\end{tabular}
a. ACGIH TLV or OSHA PEL.
b. Not established.
c. Reference 5 
The most critical contaminants (i.e., those requiring the least aerosolized sediment to reach exposure limits) were chromium, cadmium, lead, and arsenic. But even these concentrations were 2.5 to 3 orders of magnitude lower than their allowable exposure limits. For many of the organic contaminants, the margins of safety were similar or even greater. Of the organic contaminants, 2,3,7,8-TCDD (dioxin) and related dioxin-like compounds (hormone-mimicking PCBs) are of greatest concern. Dioxin, in particular, is thought to be exceedingly toxic. The US EPA has established a "normal" daily intake of dioxin-like compounds of about $120 \mathrm{pg}$ per day. ${ }^{5}$ A worker spending an entire day inhaling aerosolized sediment at a concentration of $0.1 \mathrm{mg} / \mathrm{m}^{3}$ would inhale an excess of only about $0.0013 \mathrm{pg}$ of dioxin, $1 / 100,000$ th of EPA's estimated normal daily intake.

A worst-case scenario for dioxin comes from recent data for a location on the Passaic River, New Jersey, adjacent to a former manufacturer of Agent Orange, where the average dioxin concentration was $7.7 \mu \mathrm{g} / \mathrm{kg}$ and total concentration of tetra-octachloro dioxins was $120 \mu \mathrm{g} / \mathrm{kg} .{ }^{6}$ Although metals, chlorinated pesticides, and most polynuclear aromatic hydrocarbons were present at lower concentrations than at Newtown Creek, the levels of some semi-volatile chemicals (especially chlorinated phenols), chlorinated herbicides, and dioxins and furans were significantly higher. Nevertheless, maximum airborne concentrations of contaminants, including dioxin, in aerosolized sediment were all at least 1/30th of EPA and OSHA/ACGIH exposure limits.

Shipping classification of contaminated sediments is a related concern. If sediments contain listed hazardous chemicals or exhibit one or more of the properties characteristic of a hazardous waste (i.e., flammable, reactive, corrosive, or leaches hazardous chemicals), the material may require labeling as hazardous waste. This controversial issue has been inconsistently interpreted by many regulatory agencies. Project managers are advised to review this subject before attempting to package and ship any quantity of contaminated sediments. ${ }^{7}$ Although the Newtown Creek sediments exhibited none of the properties characteristic of hazardous waste and are not classifiable as hazardous waste, this may not be the case for sediments from other locations.

2.3.2. Sediment Transport. Transport of large amounts of untreated sediments will be confined to barging to a treatment facility and internal transfers within the facility. These are routine operations with hazards similar to conventional dredging operations. Small amounts of sediments may be transported long distances for testing only.

Transport of sediments long distances poses different hazards from dredging. Perhaps the most significant is pressurization of shipping containers. Unless sediments are shipped cold or treated chemically to reduce internal decomposition reactions, gases may be generated leading to an overpressurized container; high ambient temperatures exacerbate this condition. Shipping containers should be equipped with pressure relief valves and the escaping gases evaluated for their potential to cause fires or explosions. Depending on the shape, size, and configuration of the shipping container, these internal reactions may also create an oxygen deficient environment that requires assessment before human entry.

2.3.3. Sediment Decontamination. A variety of technologies has been proposed and evaluated for the treatment of contaminated sediments (Table 1). Since a treatment process by definition seeks to change or modify the characteristics of the sediment, process side streams and effluent are also 
of concern. These could include spent solvents used to extract contaminants, stack emissions from thermal treatment systems, or residues from various separation processes. Regardless of the technology, side streams may become enriched in certain contaminants and require handling and disposal as hazardous wastes. These are discussed below.

\subsection{SAFETY PROCEDURES}

Despite the generally low risk of occupational injury during work with contaminated sediments, the following precautions should nevertheless be taken to further reduce this potential:

- Prepare and implement a project-specific health and safety plan before commencing work. The plan should be based on the best available information about the sediment dredging and treatment facilities and their operations.

- Train and equip workers for the project. Require that everyone involved in the project read, and demonstrate knowledge of the contents of the health and safety plan.

- Initially treat sediments as if they were highly contaminated. Once analytical laboratory data become available, develop personal protective equipment and work practice controls that more reasonably reflect the toxicity and concentration of the contaminants present as well as the actual potential for worker exposure.

- Segregate work areas from surrounding, non-contaminated areas with barricades, barrier tapes, or physical features of the work area. Establish work area/site access controls to preclude the entry of unauthorized persons.

- Prohibit eating, drinking, and smoking wherever sediments are handled.

- Select and use personal protective equipment according to the hazards present. Remember that overly conservative measures carry other, more immediate hazards to workers, reduce efficiency, and increase costs. Hard hats, chemically resistant outer garments, steel-toed work shoes and waterproof/chemically-resistant overboots, chemically-resistant gloves, safety glasses and face shields should be sufficient for all but the most highly contaminated sediment work. Train workers in dressing techniques to minimize the spread of contamination.

- Establish decontamination procedures for exiting the sediment handling area. Match the procedures to the contaminants present, paying particular attention to boots and gloves. A good quality detergent:water mixture is generally sufficient, although more rigorous cleaning solutions, including chemical solvents, may be needed for exotic contaminants or those present in very high concentrations. Provide for the collection and disposal of potentially contaminated equipment.

- Perform initial and periodic area and personnel monitoring for exposure indicators such as aerosol concentrations or toxic/flammable gases as indicated in the exposure assessment. Monitor weather conditions to protect against extremes of heat or cold.

- Develop contingency plans for medical emergencies and upgrading of required protective equipment, including possible respiratory protection, in the event that monitoring or field observations suggest overexposure. 


\subsection{HEALTH RISKS OF EMISSIONS TO OCCUPATIONAL ENVIRONMENTS}

2.5.1 Screening Assumptions. Occupational inhalation of toxins and carcinogens were assessed for workers in:

- A potential treatment facility in a warehouse at Port Newark; and

- The outdoor environment $100 \mathrm{~m}$ from the warehouse vent.

At the time of this analysis, there was no information on emissions from handling of these sediments or fugitive emissions from the decontamination technologies under evaluation. Initial screening assessments were, therefore, confined to examination of inhalation of contaminants under arbitrary fugitive emission rates of $100 \%, 10 \%, 1 \%$ and $0.1 \%$ of total contaminants in the sediment. The analysis assumed processing of the sediments shown in Table 2 under the conditions shown in Table 4 at a full-scale processing rate of $500,000 \mathrm{yd}^{3} / \mathrm{yr}$.

The Port Newark site assessed has a large, drafty warehouse of about $100 \mathrm{~m} \times 100 \mathrm{~m} \times 5 \mathrm{~m}$, rather like a covered football field. Buildings of this type have air infiltration rates ranging from $<1$ to about 5 air changes per hour, depending on wind speeds and characteristics of openings. ${ }^{8}$ We selected 1 air change per hour as a conservative average. Contaminants were assumed to be in equilibrium, uniformly mixed throughout the interior, and vented to the outdoors from a single roof vent. Indoor workers were assumed to occupy the building 10 hours per day for 25 working days for during pilot testing.

Outdoor workers were assumed to spend 10 hours per day at a distance of $100 \mathrm{~m}$ from the warehouse roof vent in the direction of the maximum annual average ground-level concentration as estimated with the US EPA Industrial Source Complex Model (ISCLT3). ${ }^{9}$ Meteorological dispersion of emissions vented from the warehouse was modeled under annual average meteorological conditions from Newark Airport (Table 4), which is adjacent to Port Newark. ${ }^{10}$ The warehouse was conservatively modeled as a point source, leaking only from one roof vent at ambient temperature.

Worker exposures estimated under the above assumptions were compared with US EPA Reference Doses for toxins and maximum acceptable cancer risks for carcinogens. Reference Doses (RfDs) are conservative toxicity thresholds -- maximum daily amounts per unit body weight (with a margin of safety) that can be inhaled or ingested without harm. ${ }^{11}$ Doses less than the RfD are not known to affect human health. Health risks of carcinogens were estimated using US EPA low-dose slope factors. ${ }^{12}$ These are conservative estimates of the maximum possible lifetime cancers per $\mathrm{mg}$ lifetime daily intake per $\mathrm{kg}$ body weight (with a margin of safety) at doses near zero. The slopefactor approach to quantifying carcinogenesis conservatively assumes a linear relationship without repair or threshold, which incorrectly implies that:

- Any dose can produce a quantifiable risk of cancer; and

- Ten persons receiving 1 unit of dose produces the same total risk as one person receiving 10 units of dose.

Lacking a specific threshold or cutoff point for carcinogenesis, the US EPA defines three levels of significance for maximum lifetime cancer risk: 
- Less than one in a million $\left(<10^{-6}\right)$ is de minimus ("trifling," below regulatory concern);

- Between one in a million and one in ten thousand $\left(10^{-6}\right.$ to $\left.10^{-4}\right)$ is acceptable; and

- More than one in ten thousand $\left(>10^{-4}\right)$ is unacceptable.

This screening analysis used the RfD as a cutoff level for unacceptable exposure to toxins and the $10^{-4}$ level for unacceptable maximum lifetime risk of cancer from exposure to carcinogens.

Table 4. Assumptions in screening analysis of occupational exposure to emissions from sediment decontamination.

\begin{tabular}{ll}
\hline Parameter $^{2}$ & Value \\
\hline Indoor Worker & \\
Warehouse volume & $50,000 \mathrm{~m}^{3}$ \\
Warehouse infiltration rate & 1 air change per hour \\
Emissions from treatment processes & $100 \%$ to $0.1 \%$ of total \\
Exposure duration & $2000 \mathrm{hr}$ per year for 45 years \\
Outdoor Worker & \\
Emissions from warehouse & Point source $10 \mathrm{~m}$ high \\
Emission volume & $50,000 \mathrm{~m}^{3}$ per hour \\
Plume rise & None \\
Emissions from treatment processes & $100 \%$ to $0.1 \%$ of total as fine condensation \\
& particles \\
Receptor distance & $100 \mathrm{~m}$ \\
Dispersion coefficient $(\chi / \mathrm{Q})^{\mathrm{b}}$ & $64.8 \mu \mathrm{g} / \mathrm{m}^{3}$ per $\mathrm{g} / \mathrm{sec}$ emission \\
Background particle deposition & $2.3 \mathrm{~g} / \mathrm{m}^{2} / \mathrm{yr}$ \\
Deposition coefficient & $0.5 \mathrm{~g} / \mathrm{m}^{2} / \mathrm{yr}$ per $\mathrm{g} / \mathrm{sec}$ emission \\
Exposure duration & $2000 \mathrm{hr} \mathrm{per} \mathrm{year} \mathrm{for} 45$ years \\
Dust ingestion rate & \\
$\quad$ Mean & $0.8 \mathrm{mg} / \mathrm{kg} /$ day \\
$\quad$ High & $1.4 \mathrm{mg} / \mathrm{kg} /$ day \\
\hline
\end{tabular}

a. All other meteorological modeling parameters were left at US EPA default values. ${ }^{10}$

b. US EPA ISCLT3 dispersion model. ${ }^{10}$

c. US EPA default values. ${ }^{12}$

2.5.2 Screening Results. Table 5 and Table 6 show contaminants with unacceptable levels of worker exposure at arbitrary levels of emissions from 0.1 to $100 \%$. In this table and others like it, $100 \%$ means that the entire pollution content of untreated sediments processed in one second is dispersed into the air of a $50,000 \mathrm{~m}^{3}$ warehouse in that second, and so on for smaller percentages.

From this table it is clear that the indoor environment modeled lacks sufficient dispersion to accept even $0.1 \%$ of any of the contaminants in the sediments. When so many contaminants yield high exposures in a screening analysis, however, the cause is usually overly conservative assumptions 
rather than excessive risk. This signals a need for more careful analysis of the entire exposure pathway.

Much depends on the magnitude of fugitive emissions from the various treatment methods under evaluation, which are not yet fully characterized. Since the decontamination facilities must necessarily meet OSHA standards, fugitive emissions as high as those described in the table will simply not be permitted and so these results are not applicable to any real-world situation.

Table 5. Contaminants exceeding health risk screening indicators for indoor occupational exposure at full-scale operation. ${ }^{\mathrm{a}}$

\begin{tabular}{llll}
\hline & \multicolumn{2}{c}{ Percent of total pollutant } \\
\hline $100 \%$ & $10 \%$ & $1 \%$ & $0.1 \%$ \\
\hline Occupational inhalation indoors. & & \\
\hline Arsenic & Arsenic & Arsenic & Arsenic \\
Cadmium & Cadmium & Cadmium & Cadmium \\
Chromium & Chromium & Chromium & Chromium \\
Copper & Copper & Copper & Copper \\
Lead & Lead & Lead & Lead \\
Mercury & Mercury & Mercury & Mercury \\
Nickel & Nickel & Nickel & Nickel \\
Silver & Silver & Silver & Silver \\
Zinc & Zinc & Zinc & Zinc \\
PAHs & PAHs & PAHs & PAHs \\
Cl-Pesticides & Cl-Pesticides & Cl-Pesticides & Cl-Pesticides \\
Dioxin \& Furans & Dioxin \& Furans & Dioxin \& Furans & Dioxin \& Furans \\
PCBs & PCBs & PCBs & PCBs \\
\hline
\end{tabular}

a. Under assumptions in Table 4 . 
Table 6. Contaminants exceeding health risk screening indicators for outdoor occupational exposure at full-scale operation. ${ }^{2}$

\begin{tabular}{|c|c|c|c|}
\hline \multicolumn{4}{|c|}{ Percent of total pollutant content emitted to the air } \\
\hline $100 \%$ & $10 \%$ & $1 \%$ & $0.1 \%$ \\
\hline \multicolumn{4}{|c|}{ Occupational inhalation outdoors at $100 \mathrm{~m}$} \\
\hline Arsenic & Arsenic & Arsenic & \\
\hline Cadmium & Cadmium & Cadmium & \\
\hline Chromium & Chromium & Chromium & Chromium \\
\hline Copper & Copper & & \\
\hline Lead & Lead & & \\
\hline \multicolumn{4}{|l|}{ Mercury } \\
\hline Nickel & Nickel & Nickel & \\
\hline \multicolumn{4}{|l|}{ Silver } \\
\hline \multicolumn{4}{|l|}{ Zinc } \\
\hline PAHs & PAHs & & \\
\hline Cl-Pesticides & Cl-Pesticides & & \\
\hline Dioxin \& Furans & Dioxin \& Furans & & \\
\hline PCBs & PCBs & & \\
\hline \multicolumn{4}{|c|}{ Occupational ingestion outdoors at $100 \mathrm{~m}$} \\
\hline Arsenic & Arsenic & Arsenic & Arsenic \\
\hline Cadmium & Cadmium & Cadmium & \\
\hline \multicolumn{4}{|l|}{ Chromium } \\
\hline Copper & & & \\
\hline Lead & Lead & Lead & \\
\hline Mercury & Mercury & Mercury & \\
\hline Nickel & Nickel & Nickel & Nickel \\
\hline Silver & Silver & & \\
\hline Zinc & Zinc & & \\
\hline PAHs & PAHs & PAHs & PAHs \\
\hline Cl-Pesticides & Cl-Pesticides & Cl-Pesticides & Cl-Pesticides \\
\hline Dioxin \& Furans & Dioxin \& Furans & Dioxin \& Furans & Dioxin \& Furans \\
\hline PCBs & PCBs & PCBs & \\
\hline
\end{tabular}

a. Under assumptions in Table 4. 
2.5.3 Limits on Emissions to Occupational Environments. Although at the time of this assessment there were no estimates of actual emissions from the decontamination technologies under evaluation, we can estimate the levels of emissions that would produce unacceptable exposures to workers by solving the above exposure equations (i.e., "back-calculating") for the emission rates required to produce the $\mathrm{RfD}$ or $10^{-4}$ lifetime cancer risk. These represent an upper limit on emissions against which projected future emissions from full-scale operation can be compared and with which we can determine those toxins and carcinogens that will require more careful attention.

Table 7 and Table 8 show results of these calculations. Although the limits for indoor occupational exposures appear relatively low, the industrial processes involved in most of the decontamination technologies under evaluation are common and are routinely controlled to acceptable levels using readily-available methods. We do not anticipate difficulties with meeting OSHA standards for occupational exposures.

Table 7. Emissions limits for occupational inhalation indoors at full-scale operation.

\begin{tabular}{lll}
\hline Pollutant & \multicolumn{2}{c}{ Emission Limit $^{\mathrm{a}}$} \\
\cline { 2 - 3 } Toxic Metals & $(\mathrm{kg} /$ day $)$ & $(\% \text { Total })^{\mathrm{b}}$ \\
\hline Arsenic & $3.0 \times 10^{-3}$ & $5.4 \times 10^{-3}$ \\
Cadmium & $1.0 \times 10^{-2}$ & $1.6 \times 10^{-2}$ \\
Chromium & $5.0 \times 10^{-2}$ & $8.0 \times 10^{-3}$ \\
Copper & $4.0 \times 10^{-1}$ & $2.1 \times 10^{-2}$ \\
Lead & $3.6 \times 10^{-2}$ & $3.5 \times 10^{-3}$ \\
Mercury & $3.0 \times 10^{-3}$ & $1.4 \times 10^{-1}$ \\
Nickel & $2.0 \times 10^{-1}$ & $4.0 \times 10^{-2}$ \\
Silver & $5.0 \times 10^{-2}$ & $1.6 \times 10^{-1}$ \\
Zinc & 3.0 & $1.0 \times 10^{-1}$ \\
Carcinogens & & \\
Arsenic & $3.1 \times 10^{-5}$ & $5.6 \times 10^{-5}$ \\
Cadmium & $2.5 \times 10^{-4}$ & $4.1 \times 10^{-4}$ \\
Chromium & $3.8 \times 10^{-5}$ & $1.2 \times 10^{-4}$ \\
Nickel & $9.2 \times 10^{-4}$ & $1.9 \times 10^{-4}$ \\
B2 PAHs as B[a]P & $2.1 \times 10^{-4}$ & $1.2 \times 10^{-3}$ \\
Cl-Pesticides & $9.8 \times 10^{-5}$ & 2.5 \\
Dioxins and Furans & $1.0 \times 10^{-8}$ & $1.2 \times 10^{-3}$ \\
PCBs & $3.9 \times 10^{-4}$ & $4.4 \times 10^{-3}$ \\
\hline
\end{tabular}

a. Emission rate that produces doses equal to the toxicity RfD or a lifetime cancer risk of $10^{-4}$ under assumptions in Table 4.

b. Percent of specific pollutant throughput at full-scale operation of $500,000 \mathrm{yd}^{3}$ per year. 
Table 8. Emissions limits for occupational inhalation outdoors at full-scale operation.

\begin{tabular}{lll}
\hline Pollutant & \multicolumn{2}{c}{ Emission Limit $^{\mathrm{a}}$} \\
\cline { 2 - 3 } & $(\mathrm{kg} /$ day $)$ & $\left(\%\right.$ Total $^{\mathrm{b}}$ \\
\hline Toxic Metals & & \\
Arsenic & 1.4 & 2.5 \\
Cadmium & 4.7 & 7.5 \\
Chromium & 23 & 3.7 \\
Copper & 190 & 9.5 \\
Lead & 17 & 1.6 \\
Mercury & 1.4 & 65 \\
Nickel & 93 & 19 \\
Silver & 23 & 75 \\
Zinc & 1400 & 48 \\
Carcinogens & & \\
Arsenic & 0.064 & 0.11 \\
Cadmium & 0.51 & 0.82 \\
Chromium & 0.078 & 0.25 \\
Nickel & 1.9 & 0.38 \\
B2 PAHs as B[a]P & 0.44 & 2.5 \\
Cl-Pesticides & 0.20 & $>100$ \\
Dioxins and Furans & $2.1 \times 10^{-5}$ & 2.4 \\
PCBs & 6.5 & 74 \\
\hline
\end{tabular}

a. Emission rate that produces doses equal to the toxicity $\mathrm{RfD}$ or a lifetime cancer risk of $10^{-4}$ under assumptions in Table 4 .

b. Percent of specific pollutant throughput at full-scale operation of $500,000 \mathrm{yd}^{3} / \mathrm{yr}$.

\subsection{DISCUSSION}

In general, because of similarities in physical processes, we anticipate that fugitive emissions will be similar within categories of technologies using: (1) low temperature; (2) high temperature; and (3) solvent extraction. Potential fugitive emissions from low-temperature technologies will be confined to gases (e.g., $\mathrm{H}_{2} \mathrm{~S}$ ), any organics that can volatilize at low temperatures, and fugitive dusts, including dusts from process chemicals (e.g., cement from stabilization processes). It is unlikely that metals or particle-bound organics will be emitted from low-temperature treatment technologies. Potential fugitive emissions from high-temperature technologies will include volatile metals (e.g., lead, mercury, arsenic), volatilized organics, and residual products from combustion of organics. Temperatures are high, however, so only fugitive emissions occurring before complete combustion have much potential to affect health. Potential fugitive emissions from solvent extraction technologies are primarily the solvents themselves, the constituents and hazards of which differ among solvent-based technologies. 


\section{PUBLIC HEALTH RISKS}

\subsection{EMISSIONS TO RESIDENTIAL ENVIRONMENTS}

3.1.1 Screening Analysis. A hazardous substance is one that can produce a detrimental effect. The term "hazardous" is routinely misinterpreted as "harmful." But that a substance can produce a detrimental effect does not mean that it will do so in every circumstance. Even the most toxic poison must be consumed at a sufficient dose to be harmful. A health risk screening analysis identifies those hazardous substances that are not expected to produce harmful exposures in a particular circumstance.

The purpose of a screening analysis is to reduce the level of effort required to quantify health and environmental risks. A back-of-the-envelope estimate is made based on ultra-simplified, conservative assumptions that yield a result many times higher than could realistically be expected. This crude overestimate identifies contaminants that have such low risks that they are of no health or environmental concern. Contaminants and pathways shown to be insignificant in a screening analysis will be even less significant in detailed and more realistic analyses, and so are eliminated from further analysis.

3.1.2 Screening Assumptions. This screening analysis addresses doses from inhalation and ingestion by individuals at greatest risk of exposure to emissions and effluents produced during dredging and treatment of contaminated sediments. Figure 1 shows the study area around the Port Newark site. Table 9 shows the assumptions used.

The inhalation pathway was examined for:

- Public exposures to residents of the closest residential neighborhood by Hudson River Park in Bayonne.

The ingestion pathway was examined for:

- Consumption of surface dust by children and adults at the nearest residential neighborhood; and

- Consumption by recreational fishermen of seafood from Newtown Creek, NY or other similar portions of the harbor (e.g., Newark Bay) before dredging.

We judged all other potential pathways (e.g., consumption of produce grown near the site) to be extremely unlikely and so of no significance at the location studied.

The nearest resident was assumed to be on the eastern shore of Newark Bay $2250 \mathrm{~m}$ ESE of the warehouse (Hudson County Park) for 24 hours per day. Indoor concentrations were assumed equal to outdoor concentrations. Contaminant concentrations. were estimated with the US EPA ISCLT3 meteorological dispersion model under the assumptions in Table 9 (Figure 2). ${ }^{10}$ Particles deposited at the nearest residence were assumed to be only fine condensates generated by high-temperature decontamination processes. Deposition of particles to surfaces was assumed to combine with a 
background particle deposition rate of $2.3 \mathrm{~g} / \mathrm{m}^{2} / \mathrm{yr} .{ }^{11}$ Because ambient particle concentration in the area is high at $43 \mu \mathrm{g} / \mathrm{m}^{3},{ }^{5}$ we assumed the facility will not be permitted to emit more than whatever will bring the total to the standard of $50 \mu \mathrm{g} / \mathrm{m}^{3}$. Thus, deposited contaminants were assumed to be mixed in a total particle deposition of $2.7 \mathrm{~g} / \mathrm{m}^{2} / \mathrm{yr}$. Contaminants from other sources in the background deposition were ignored at this screening level of assessment.

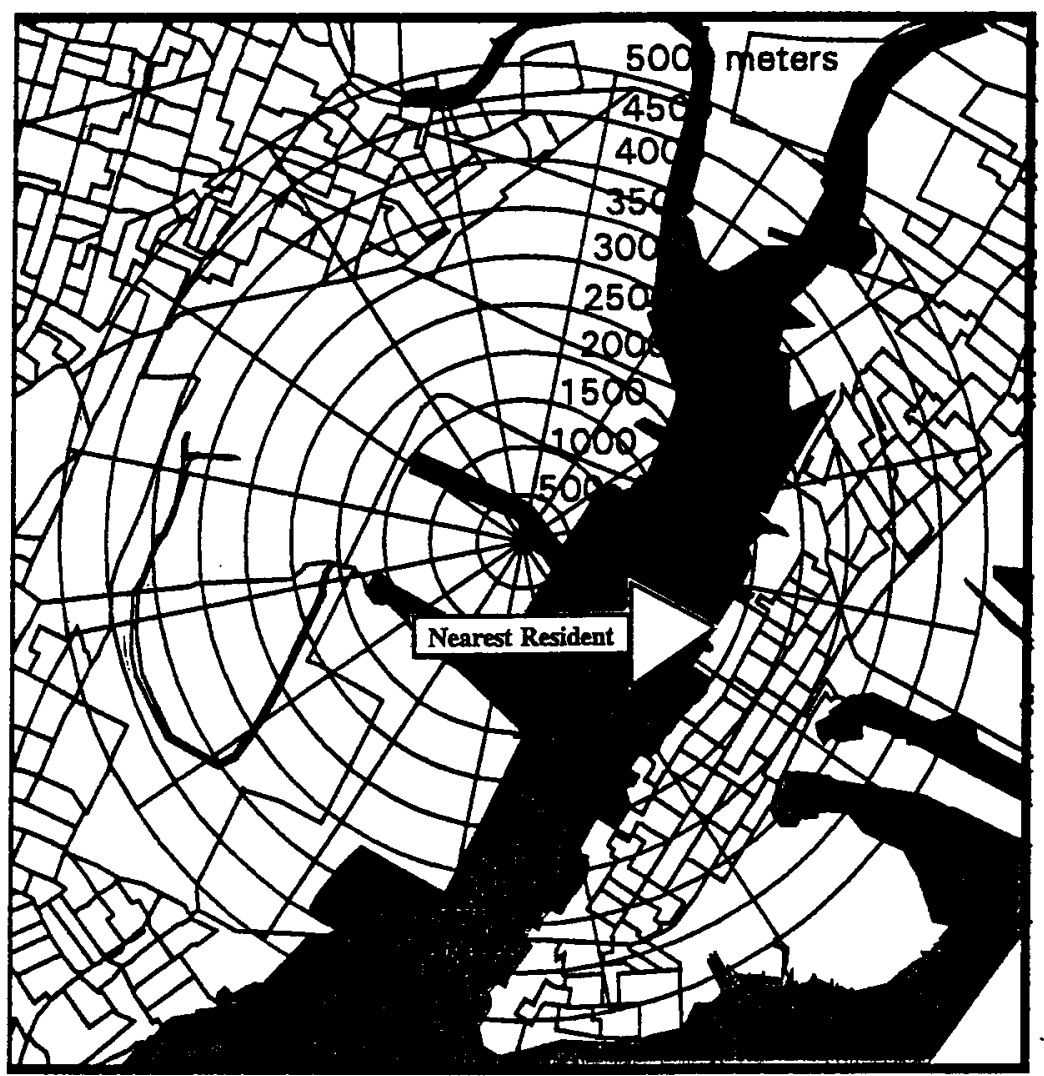

Figure 1. Port Newark Study Area. 
Table 9. Assumptions in screening analysis of public exposure to emissions from sediment decontamination.

\begin{tabular}{|c|c|}
\hline Parameter & Value \\
\hline \multicolumn{2}{|l|}{ Inhalation of contaminated dust } \\
\hline Emissions from warehouse & Point source at $10 \mathrm{~m}$ \\
\hline Plume rise & None \\
\hline Emissions from treatment processes & $100 \%$ to $0.1 \%$ of total \\
\hline Receptor distance & $2250 \mathrm{~m}$ \\
\hline Dispersion coefficient $(\chi / Q)^{b}$ & $0.11 \mu \mathrm{g} / \mathrm{m}^{3}$ per $\mathrm{g} / \mathrm{sec}$ emission \\
\hline Duration of exposure & $24 \mathrm{hr} /$ day for 70 years \\
\hline \multicolumn{2}{|l|}{ Ingestion of contaminated dust } \\
\hline Emissions from treatment processes & Fine condensation particles \\
\hline Background particle deposition & $2.3 \mathrm{~g} / \mathrm{m}^{2} / \mathrm{yr}$ \\
\hline Maximum deposition & $2.7 \mathrm{~g} / \mathrm{m}^{2} / \mathrm{yr}$ \\
\hline Deposition coefficient & $7.0 \times 10^{-4} \mathrm{~g} / \mathrm{m}^{2} / \mathrm{yr}$ per $\mathrm{g} / \mathrm{sec}$ emission \\
\hline Duration of exposure & 70 years \\
\hline \multicolumn{2}{|l|}{ Dust ingestion rate ${ }^{c}$} \\
\hline Mean & $5 \mathrm{mg} / \mathrm{kg} /$ day child, $0.8 \mathrm{mg} / \mathrm{kg} /$ day adult \\
\hline High & $40 \mathrm{mg} / \mathrm{kg} /$ day child, $1.4 \mathrm{mg} / \mathrm{kg} /$ day adult \\
\hline \multicolumn{2}{|c|}{ Ingestion of recreational seafood from Newtown Creek } \\
\hline Sediment contamination & Existing conditions, no dredging \\
\hline Biota-sediment accumulation factors & $\begin{array}{l}\text { Highest average animal-specific factor } \\
\text { from EMAP and NYC DEP data. }{ }^{13,14}\end{array}$ \\
\hline \multicolumn{2}{|l|}{ Recreational seafood consumption ${ }^{d}$} \\
\hline Mean & $0.43 \mathrm{~g} / \mathrm{kg} /$ day \\
\hline High & $2.0 \mathrm{~g} / \mathrm{kg} /$ day \\
\hline
\end{tabular}

a. All other meteorological modeling parameters were left at US EPA default values. ${ }^{10}$

b. US EPA ISCLT3 dispersion model. ${ }^{10}$

c. US EPA default values. ${ }^{15}$

d. For reference and methodology development only. Data are not yet developed for contamination of seafood by dredging or processing. 


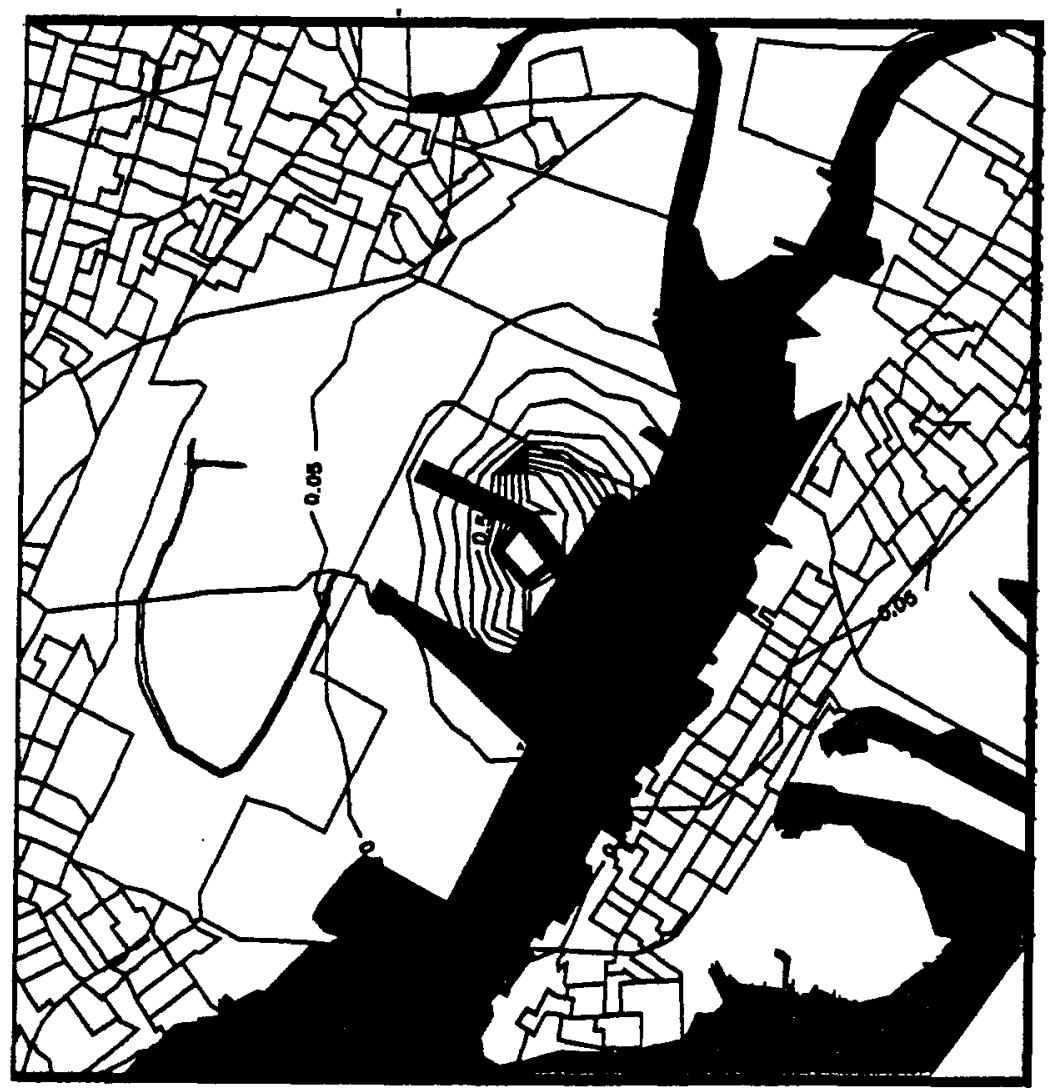

Figure 2. Concentration per unit emission.

As was done for occupational exposures, in the absence of data on emissions from the decontamination facility, initial screening assessments are confined to examination of exposures under the conditions shown in Table 9 at several arbitrary external emission rates expressed as percent of total contaminant released at full-scale operation, and also the emission rates (limits) required to produce exposures equal to public health-risk limits at full-scale operation.

In addition, as a point of reference and to establish an analytical methodology, we also evaluated potential public exposures from consumption of recreational seafood caught in Newtown Creek under current conditions as shown in Table 9. This was taken to be an extreme worst-case analysis, as dredging in any part of the harbor is expected to leave bottom conditions much cleaner than those currently existing in Newtown Creek. There are no data at this time on the potential contamination of seafood from dredging or decontamination of sediments. Therefore, we do not yet know if these results are useful for evaluating future operational conditions. 
3.1.3 Screening Results. Potential health risks of toxic metals were quantified by comparison with US EPA's Reference Doses (RfDs) and potential health risks of carcinogens were estimated using US EPA's low-dose slope factors (see Section 2.5.1). Table 10 shows contaminants exceeding either health risk indicator as a function of various arbitrary levels of emission.

Results of the screening analysis show that:

- A processing rate of $500,000 \mathrm{yd}^{3} / \mathrm{yr}$ yields relatively high potential exposures to arsenic and nickel by ingestion of dust from environmental surfaces.

- Consumption of recreational seafood from the harbor under current conditions in many places is clearly not healthy. Dredging should contribute significantly to reducing contamination in fish in those areas. For the sediments assessed, toxicity limits are exceeded for arsenic, cadmium, lead, mercury, and zinc. Cancer risk limits are exceeded for chlorinated pesticides and dioxins and furans. The latter two carcinogens are most likely to require special attention.

\subsection{LIMITS ON EMISSIONS TO RESIDENTIAL ENVIRONMENT}

Pollutant emissions limits for residential exposures are estimated in the same was as those for occupational exposures (Section 2.5.3). Calculation of pollution emission limits is based on the same data and assumptions as the screening (Table 9), at a full-scale processing rate of 500,000 $\mathrm{yd}^{3} / \mathrm{yr}$ of sediments. Emissions limits for inhalation and ingestion of toxins and carcinogens are shown in Table 11 and Table 12. An emission limit of 5\% or less of the throughput of a pollutant signal a need for closer attention, since it is not unusual that up to $5 \%$ of many pollutants might escape from many kinds of processes.

Most of the limits for inhalation exceed the production rate. Only the limit for arsenic approaches a level that might realistically be encountered. So we do not expect the inhalation pathway to endanger public health at a distance of $2250 \mathrm{~m}$ or more.

The emission limits for ingestion of dust on environmental surfaces suggest there may be need to give special attention to emissions of arsenic, lead, nickel, PAHs, and dioxins and furans. The latter two are not expected to be emitted in significant amounts from low-temperature processes and are easily controlled to the necessary levels in high-temperature processes. But exposure to arsenic, lead, and nickel by the ingestion route should receive closer attention in future assessments.

\subsection{HEALTH RISKS OF ALTERNATIVES}

There is a tendency among engineers to simplify analyses by evaluating a few set alternatives based on standard practice. With respect to health risks, this usually means one level of environmental control. Often, that level is determined by environmental regulations. As a result, we forget that any alternative actually includes a continuum of emissions and potential health risks, the magnitude of which depends mostly on the amount of money we are willing to spend to control them. Modest levels of control are usually relatively cheap and easy. Higher levels of control become increasingly 
difficult and expensive per unit success. And at some point, the cost of additional controls per unit reduction in risk simply becomes unreasonable. There are no alternatives that are free of risk. Thus, we should evaluate the health risks of the alternatives not only with respect to standard practice, but also keeping in mind that a particularly desirable alternative with relatively harmful emissions can be improved by additional expenditures, provided we are willing to pay.

Table 10. Contaminants exceeding health risk screening indicators at nearest residence at full-scale operation. ${ }^{a}$

\begin{tabular}{|c|c|c|c|}
\hline \multicolumn{4}{|c|}{ Percent of total pollutant content emitted to the air } \\
\hline $100 \%$ & $10 \%$ & $1 \%$ & $0.1 \%$ \\
\hline \multicolumn{4}{|l|}{ Inhalation } \\
\hline Arsenic & Arsenic & & \\
\hline \multicolumn{4}{|l|}{ Cadmium } \\
\hline \multicolumn{4}{|l|}{ Chromium } \\
\hline \multicolumn{4}{|l|}{ Nickel } \\
\hline \multicolumn{4}{|l|}{ Ingestion of Dust } \\
\hline Arsenic & Arsenic & Arsenic & Arsenic \\
\hline \multicolumn{4}{|l|}{ Cadmium } \\
\hline \multicolumn{4}{|l|}{ Copper } \\
\hline \multicolumn{4}{|l|}{ Lead } \\
\hline Nickel & Nickel & Nickel & Nickel \\
\hline PAHs & PAHs & PAHs & \\
\hline Cl-Pesticides & Cl-Pesticides & Cl-Pesticides & \\
\hline Dioxin \& Furans & Dioxin \& Furans & Dioxin \& Furans & \\
\hline PCBs & PCBs & & \\
\hline \multicolumn{4}{|c|}{ Ingestion of Recreational Seafood ${ }^{b}$} \\
\hline Arsenic & Arsenic & Arsenic & \\
\hline Cadmium & Cadmium & Cadmium & \\
\hline Lead & & & \\
\hline Mercury & Mercury & & \\
\hline Zinc & & & \\
\hline Cl-Pesticides & Cl-Pesticides & Cl-Pesticides & Cl-Pesticides \\
\hline Dioxin \& Furans & Dioxin \& Furans & Dioxin \& Furans & Dioxin \& Furans \\
\hline
\end{tabular}

a.. Processing $500,000 \mathrm{yd}^{3} / \mathrm{yr}$.

b. Unprocessed sediments from Newtown Creek. 
Table 11. Emissions limits for residential inhalation at full-scale operation.

\begin{tabular}{lrr}
\hline Pollutant & \multicolumn{2}{c}{ Emission Limit } \\
\cline { 2 - 3 } & (kg/day) & $(\% \text { Total })^{\mathrm{b}}$ \\
\hline Toxic Metals $^{\mathrm{c}}$ & & \\
Arsenic & 820 & $>100$ \\
Cadmium & 2,700 & $>100$ \\
Chromium & 14,000 & $>100$ \\
Copper & 110,000 & $>100$ \\
Lead & 9,900 & $>100$ \\
Mercury & 820 & $>100$ \\
Nickel & 55,000 & $>100$ \\
Silver & 14,000 & $>100$ \\
Zinc & 820,000 & $>100$ \\
Carcinogens & & \\
Arsenic & & 9.8 \\
Cadmium & 5.5 & 71 \\
Chromium & 44 & 21 \\
Nickel & 6.7 & 32 \\
B2 PAHs as B[a]P & 160 & $>100$ \\
Cl-Pesticides & 38 & $>100$ \\
Dioxins and Furans & 17 & $>100$ \\
PCBs & 0.0018 & $>100$ \\
\hline
\end{tabular}

a. Emission rate that produces doses equal to the toxicity $\mathrm{RfD}$ or a lifetime cancer risk of $10^{-4}$. Nearest residence is $2250 \mathrm{~m}$ from Port Newark.

b. Percent of pollutant throughput at full-scale operation of $500,000 \mathrm{yd}^{3} / \mathrm{yr}$.

c. Short-term exposure to child $<7$ years old.

d. Lifetime exposure. 
Table 12. Emissions limits for residential ingestion at full-scale operation. Limits $55 \%$ are highlighted.

\begin{tabular}{|c|c|c|}
\hline \multirow[t]{2}{*}{ Pollutant } & \multicolumn{2}{|c|}{ Emission Limit $^{2}$} \\
\hline & (kg/day) & $(\% \text { Total })^{b}$ \\
\hline \multicolumn{3}{|l|}{ Toxic Metals $^{c}$} \\
\hline Arsenic & 2.5 & 4.4 \\
\hline Cadmium & 8.3 & 13 \\
\hline Chromium & 8,300 & $>100$ \\
\hline Copper & 330 & 17 \\
\hline Lead & 30 & 2.9 \\
\hline Mercury & 2.5 & $>100$ \\
\hline Nickel & 170 & 33 \\
\hline Silver & 41 & $>100$ \\
\hline Zinc & 2,200 & 86 \\
\hline \multicolumn{3}{|l|}{ Carcinogens $^{d}$} \\
\hline Arsenic & 0.067 & 0.22 \\
\hline Cadmium & NA & \\
\hline Chromium & NA & \\
\hline Nickel & 2.0 & 0.74 \\
\hline $\mathrm{B} 2$ PAHs as $\mathrm{B}[\mathrm{a}] \mathrm{P}$ & 88 & 4.8 \\
\hline Cl-Pesticides & 40 & $>100$ \\
\hline Dioxins and Furans & 0.0043 & 4.8 \\
\hline PCBs & 83 & 6.5 \\
\hline
\end{tabular}

a. Emission rate that produces doses equal to the toxicity RfD or a lifetime cancer risk of $10^{-4}$. Nearest residence is $2250 \mathrm{~m}$ from Port Newark.

b. Percent of pollutant throughput at full-scale operation of $500,000 \mathrm{yd}^{3} / \mathrm{yr}$.

c. Short-term exposure to child $<7$ years old.

d. Lifetime exposure.

All of the decontamination technologies under study (Table 1) have potential to produce leachates to the bay from handling and dewatering of raw sediments which could eventually expose the public through consumption of recreational seafood. These discharges are heavily regulated, however, so potential human exposure is minimal. The most important source of contamination in recreational seafood is the in-place sediments themselves. It is not clear whether stirring and leaching of sediments during handling and dewatering, followed by dilution in the cleaner surface waters of the harbor, can increase human exposure over that already produced by in-place sediments. This pathway should be examined in more detail.

Decontamination technologies can be characterized with respect to potential public health risks by process temperature and by use of potentially hazardous additives. Low-temperature processes include surfactant-based soil washing, solvent extraction, and chemical stabilization. Except for solvent extraction, which uses a volatile organic solvent, these have limited capability to produce emissions to the air because of the non-destructive nature of the processing, and they are well 
understood chemically so effluents to water can be controlled readily if necessary. The primary exposure pathway will probably be ingestion of contaminated recreational seafood from whatever effluents may escape to the harbor from small-scale spillage and runoff. The solvent extraction process can also release volatile components of the added solvents if the equipment is not correctly designed and operated. Inhalation of fugitive emissions from small leaks in processing equipment are the most likely source of human exposure. Solvent-based processes are common in industry, however, and the technology for controlling emissions is well established. There is no reason to expect that these processes cannot be controlled to acceptable levels using normal industrial techniques and good engineering practice.

Heat-based processes include exothermic chemical stabilization, thermal desorption, and vitrification. Modest-temperature processes, such as exothermic chemical stabilization or thermal desorption can volatilize contaminants. Processes using very high temperatures, such as plasma-arc vitrification, involve temperatures so high that it is unlikely the organic contaminants can survive unchanged. Volatilization of metals such as arsenic and mercury, however, could be a problem with these processes, so it will be necessary that they be controlled for metal-containing aerosols. Based on our preliminary screening analysis, ingestion of contaminated dust on surfaces appears to be the most important exposure pathway for heat-based processes, althugh direct inhalation must also be evaluated. Again, controlling these kind of problems is routine and well understood in the industry.

\subsection{ODORS}

In addition to potential health risks, odors emanating from a facility processing hazardous materials of any kind will cause severe problems with perceived risks, regardless of their significance for human or environmental health. Odors have immense "signal value." The public first assumes that the odor, itself, is hazardous. Then, if convinced otherwise -- not always easy -- they assume that the odor is linked to hazardous emissions that cannot be smelled, which is even worse. Perceived risks are routinely inflated by mistrust and fears of the unknown.

Odor control may be the most important technical requirement in the entire dredging, transport, and decontamination process because of its importance to public acceptance.

\subsection{HEALTH RISKS OF BENEFICIAL USES}

The beneficial uses and market potentials evaluated by the US Army Corps of Engineers include ocean, aquatic, and upland applications. ${ }^{16}$ The Corps concludes that ocean and upland applications are feasible, but the potential for decontaminated dredged material to be used beneficially in the aquatic environment is limited. Decontaminated products evaluated by the Corps as "realistic" include:

$\begin{array}{lll}\text { Cement } & \text { Asphalt } & \text { Blending facilities } \\ \text { Mining reclamation } & \text { Fast land } & \text { Artificial reefs } \\ \text { Coastal restoration } & \text { Pesticide carriers } & \text { Fill } \\ \text { Man-made ponds } & \text { Glass } & \\ \text { Fertilizer enhancers } & \text { Soils } & \end{array}$


Produces evaluated as "less realistic" include:

$\begin{array}{lll}\text { Oil recovery } & \text { Research } & \text { Soil insulation } \\ \text { Filtering medium } & \text { Foundry sand } & \text { Direct sales }\end{array}$

There was a general acceptance of the products, so long as they performed as well as existing materials. But there is little incentive for potential users to switch from existing materials unless the new products cost less.

The beneficial uses proposed for the alternatives under study are of two types with respect to potential health and environmental impacts: (1) loose materials, such as manufactured soil or dirt for landfill cover or backfill; and (2) solid building materials. Loose materials are primarily subject to resuspension and leaching to ground water, so they must meet established environmental criteria for these materials, particularly with respect to leachability. ${ }^{17,18}$ Volatile organic contaminants vaporize and are not likely to remain long enough to pose a problem from reuse. The treatment processes will be designed specifically to produce a product in compliance with the intended use and, therefore, the materials will not pose significant additional health risk over other materials used for the same purpose.

Solid building materials of the kinds proposed are not normally regulated with respect to leachability or emissions of volatile contaminants. All of these solids are, however, resistant to leaching or volatilization, and they must also be tested specifically for these properties as part of the technology characterization process. Leaching and emission rates of test samples were exceedingly low.

\subsection{DISCUSSION}

The above results suggest that ingestion of contaminated particles is the exposure pathway most likely to be of concern with respect to public health. The sediment decontamination methods under study (Table 1) can be characterized with respect to deposition of contaminated particles by process temperature.

Low-temperature processes, such as soil washing and cement stabilization, can resuspend dry sediments, but these are relatively heavy particles that cannot travel far from the facility before settling out. We do not expect that dry sediment particles will contribute to dust available for ingestion at distances greater than about $1000 \mathrm{~m}$. More careful analysis of fugitive dusts will be required if there are residences closer to the treatment facility. If necessary, dry yard dusts are easily controllable.

High-temperature processes, such as thermal desorption or vitrification, can volatilize organic constituents and some metals which, if they escape from the process, can condense to form fine particles or fluffy, low-density particles that can be transported longer distances on the wind. This class of particles is relatively easy to control, however, so there is no reason to believe that the proposed treatment processes will be unable to meet routine emissions standards and acceptable levels of health risk. 


\section{CONCLUSIONS AND RECOMMENDATIONS}

Working with contaminated sediments poses a variety of potential safety and health hazards to workers and, to a lesser extent, to the nearby public. Although detectable quantities of toxic chemicals are present in many sediments, their generally low concentration (at least relative to industrial settings) and the wet form of most sediments make excessive worker exposures unlikely during most sampling and dredging work. Ingestion and dermal exposures can be minimized or eliminated effectively by implementation and enforcement of basic personal hygiene and protective equipment requirements. Inhalation exposures, either to chemical vapors or from aerosols of contaminated sediment, are also unlikely, unless the contaminant concentrations are very high or the work involves sediment heating or turbulent handling which generates aerosols. Physical safety hazards are likewise relatively minor and easily managed.

Screening analysis of occupational inhalation of toxins and carcinogens demonstrates a potential for exceeding health-based exposure limits for several contaminants if fugitive emissions are not controlled. Some attention must be given to controlling fugitive emissions to ensure compliance with OSHA standards.

Public health risks of the decontamination technologies under study are determined by process temperatures and use of hazardous additives. Low-temperature processes have limited capability to emit contaminants to the air. Except for solvent extraction, public health risks are mostly confined to leachates that may escape to harbor waters and be consumed in recreational seafood, and possibly fugitive dusts if there are residences very close to the treatment facility. Solvent extraction has potential to emit volatile solvents to the air from small process leaks. These emissions are subject to environmental regulations and the appropriate controls are well established. Modest-temperature processes can volatilize organic contaminants and some metals. Based on preliminary screening analyses, ingestion of deposited particles containing volatilized contaminants has potential to be an important exposure pathway. These emissions must be examined carefully and controlled as necessary to ensure protection of nearby residents. High-temperature processes are unlikely to emit significant amounts of organic contaminants because the contaminants cannot survive the heat. Volatilized metals can survive, however, so particle emissions from these processes must also be controlled.

Although this analysis demonstrates that decontamination processes are not likely to pose unacceptable risks to public health from most contaminants in the sediments, screening results identify ingestion of arsenic and nickel in dust deposited on environmental surfaces as a potentially important exposure pathway requiring special attention in future assessments.

Stringent control of odors throughout the dredging, transport, and decontamination process is essential. Perceived risks from odors can be a greater impediment to the success of a decontamination effort than real risks. 


\section{ACRONYMS}

ACGIH American Conference of Governmental Industrial Hygienists

BSAF

$\mathrm{Cl}-$ Biota:sediment accumulation factor

AEL Chlorinated

EMAP Allowable Exposure Limit

EPA

ESE Environmental Monitoring and Assessment Program

IRIS Environmental Protection Agency

ISCLT3 East by southeast Industrial Source Complex Model

NYC DEP New York City Department of Environmental Protection

OSHA

PAHs

PCBs

PEL

$\bar{R} \mathrm{fD}$

TCDD

TCDF

TLV

UV Occupational Safety and Health Administration Polycyclic aromatic hydrocarbons

Polychlorinated biphenyls Permissible exposure limit Reference dose tetrachloro dibenzo-p-dioxin tetrachloro dibenzofuran Threshold Limit Value Ultraviolet 


\section{REFERENCES}

1. Draft Final Report on "Section 405C of Water Resources Development Act of 1992, Fast Track Sediment Decontamination Demonstration." Brookhaven National Laboratory, Upton, NY. April 1997.

2. US Department of Labor. Occupational Injuries and Illnesses in the United States by Industry, 1990. Bureau of Labor Statistics Report, 1992.

3. Occupational Safety and Health Administration. Air contaminants - Permissible Exposure Limits, 29 CFR Part 1910-1000 (Z1 \& Z2).

4. Threshold Limit Values for Chemical Substances and Physical Hazards and Biological Exposure Indices. American Conference of Governmental Industrial Hygienists, Cincinnati, $\mathrm{OH}$, 1996.

5. Dioxin Risk Characterization (Vol. III of the EPA Health Assessment Document for 2,3,7,8-tetrachlorodibenzo-p-dioxin and Related Compounds). EPA/600/6-88/005ca(disk). US Environmental Protection Agency, Washington, DC. September 1994.

6. Stern, E. Personal communication. US Environmental Protection Agency, Region II, New York, NY, 1996.

7. US Environmental Protection Agency, Resource Conservation and Recovery Act. 40 CFR Part 261.

8. Ashley, J.L., and P.L. Langus. Air infiltration measurements in large military aircraft hangars. IN H.R. Trechsel and P.L. Lagus (Eds), Measured Leakage of Buildings. ASTM Special Technical Publication 904. American Society for Testing and Materials, Philadelphia, PA, 1986.

9. Draft User's Guide for the Industrial Source Complex (ISC3) Dispersion Models (Revised). EPA-454/B-95-003a and b. US Environmental Protection Agency, Research Triangle Park, NC. July 1995.

10. Unpublished monitoring data from Elizabeth and Newark, NY, 1990-1994. Office of Air Quality Management, Department of Environmental Protection, State of New Jersey, Trenton, NY. September 1995.

11. Integrated Risk Information System (IRIS) database. U.S Environmental Protection Agency, Washington, DC. September 1995.

12. Exposure Factors Handbook. US Environmental Protection Agency, Washington, DC, 1990. 
13. Estuaries Program level database (EMAP). Virginian Province: 1990-1993, Stations in the New York Harbor Region. Environmental Research Laboratory, US Environmental Protection Agency, Narragansett, RI, 1995.

14. Brosnan, T. Unpublished data. Marine Sciences Section, New York City Department of Environmental Protection, New York, NY, 1991-1992.

15. Exposure Factors Handbook. US Environmental Protection Agency, Washington, DC, 1990.

16. Investigation of End-Disposal Testing Criteria and Suitability and Beneficial Uses of Treated Dredged Material from New York/New Jersey Harbor. US Army Corps of Engineers Waterways Experiment Station, 31 January 1997.

17. Summary of Proposed Ammendments to 6 NYCRR Part 360, Solid Waste Management Facilities. Division of Solid \& Hazardous Materials, New York State Department of Environmental Conservation, Albany, NY. March 1997.

18. Montague, A. The Introduction of Processed Sediment for Soil, Construction, and Industrial Uses (Draft). Submitted to US Army Corps of Engineers - WES by M\&S Associates, Beverly, MA. July 15, 1996. 
